\title{
HUBUNGAN DAYA LEDAK TUNGKAI DAN KOORDINASI MATA TANGAN TERHADAP KEMAMPUAN SMASH BOLAVOLI MAHASISWA PROGRAM STUDI PENDIDIKAN KEPELATIHAN OLAHRAGA FAKULTAS OLAHRAGA DAN KESEHATAN UNIVERSITAS NEGERI GORONTALO
}

\author{
Edy Dharma Putra Duhe ${ }^{1}$, Resa Sukardi Massa ${ }^{2}$
}

Keywords :

Daya Ledak Tungkai;

Koordinasi Mata Tangan;

Smash Bolavoli.

\section{Corespondensi Author \\ ${ }^{1}$ Universitas Negeri Gorontalo, edy.dharma81@gmail.com \\ 2 Universitas Negeri Gorontalo, resasetter@gmail.com}

\author{
Article History \\ Received: Agustus \\ Reviewed: September \\ Accepted: September \\ Published: Oktober
}

\begin{abstract}
ABSTRAK
Penelitian ini bertujuan untuk mengetahui hubungan daya ledak tungkai dan koordinasi mata tangan terhadap kemampuan smash bolavoli. Populasi pada penelitian ini adalah seluruh mahasiswa Program Studi Pendidikan Kepelatihan Olahraga Fakultas Olahraga dan Kesehatan Universitas Negeri Gorontalo dengan jumlah sampel penelitian 30 orang yang dipilih secara random sampling. Teknik analisis data yang digunakan adalah teknik analisis korelasi dan regresi dengan menggunakan sistem SPSS Versi 20.0 pada taraf signifikan $95 \%$ atau $\alpha_{0,05}$. Bertolak dari hasil analisis data, maka penelitian ini menyimpulkan bahwa: (1) Ada hubungan yang signifikan daya ledak tungkai terhadap kemampuan smash bolavoli mahasiswa Program Studi Pendidikan Kepelatihan Olahraga Fakultas Olahraga dan Kesehatan Universitas Negeri Gorontalo, terbukti $r_{0}=0,823(P<\alpha 0,05)$, (2) Ada hubungan yang signifikan koordinasi mata tangan terhadap kemampuan smash bolavoli Program Studi Pendidikan Kepelatihan Olahraga Fakultas Olahraga dan Kesehatan Universitas Negeri Gorontalo, terbukti $r_{0}=0,646(P<\alpha 0,05)$, (3) Ada hubungan yang signifikan daya ledak tungkai dan koordinasi mata tangan terhadap kemampuan smash bolavoli mahasiswa Program Studi Pendidikan Kepelatihan Olahraga Fakultas Olahraga dan Kesehatan Universitas Negeri Gorontalo terbukti $R_{0}$ $=0,829(P<\alpha 0,05)$.
\end{abstract}

\section{PENDAHULUAN}

Permaianan bolavoli perkembangannya semakin dapat diterima dan digemari oleh mahasiswa, gejala ini terjadi karena permainan bolavoli merupakan olahraga yang cukup menarik. Walaupun sederhana dalam bentuk permainannya seseorang hanya bisa bermain bolavoli dengan baik bila mampu melakukan teknik-teknik gerakan yang sesuai dengan peraturan permaianan. Permainan akan semakin menarik apabila mahasiswa mampu menguasai daya ledak lengan, daya ledak tungkai dan koordinasi mata tangan terhadap kemampuan smash pada permainan bolavoli. Salah satu cabang olahraga yang diajarkan dalam kurikulum pendidikan kepelatihan olahraga adalah permainan bolavoli. Permainan bolavoli adalah suatu jenis olahraga permainan ini di mainkan oleh dua regu yang saling berhadapan yang masingmasing regu terdiri dari enam pemain, setiap regu berusaha dapat memukul dan 


\section{Volume 10 Nomor 3, Oktober 2018}

menjatuhkan bola ke dalam lapangan melewati di atas jaring atau net dan mencegah pihak lawan dapat memukul dan menjatukan bola ke lapangannya. Bola di mainkan dengan di awali servis dan masing-masing regu di beri ke sempatan maksimal tiga kali sentuhan oleh pemain yang berbeda dan untuk mengembalikan bola ke lawan melewati atas net. Regu yang dapat menjatukan bola di daerah lawan dan berhasil mengumpulkan poin, itulah yang menjadi pemenang dalam permainan bolavoli. Permainan bolavoli merupakan salah satu permainan bola besar yang dimainkan oleh dua regu yang saling bertanding (Giriwijoyo,2007:10). Permainan bolavoli adalah permainan yang membutuhkan koordinasi gerak, kekuatan, kecepatan, kelincahan, power, daya ledak lengan, daya ledak tungkai yang baik. Sehubungan dengan koordinasi gerak dalam permainan bolavoli kendala yang dihadapi oleh mahasiswa dalam menguasai keterampilan adalah kurangnya kemampuan kondisi tubuh yang dimiliki antara lain, kekuatan, kecepan, kelincahan, daya tahan kepada reaksi, power, daya ledak lengan, daya ledak tungkai, koordinasi mata tangan dan lain-lain. Ada beberapa keterampilan atau teknik dasar yang perlu dikuasi oleh seorang mahasiswa dalam permainan bolavoli antara lain passing bawah, passing atas, servis, smash dan blok. Smash merupakan teknik dasar yang selalu digunakan untuk menyerang dan menghasilkan angka serta meraih kemenangan. Karena permainan bolavoli merupakan permainan cepat maka teknik menyerang lebih dominan dibandingkan dengan teknik bertahan. Beberapa faktor yang mempengaruhi dalam menguasai teknik smash dalam permainan bolavoli adalah ketepatan saat melakukan awalan, ketepatan saat meloncat dan ketepatan saat memukul bola. Sedangkan faktor pendukung smash yaitu pemberian bola pada smasher yang bersangkutan serta blok. Blok merupakan benteng pertahanan yang utama untuk menangkis serangan lawan. Pada posisi empat dan dua serangan pada umumnya dilakukan dengan bola-bola tinggi, efektif menghasilkan angka. Umpan bola tinggi membentuk daerah sasaran lebih luas sehingga memudahkan smasher untuk menempatkan bola ke daerah sasaran yang diinginkan. Sedangkan pada posisi tiga serangan yang dilakukan dengan bola-bola sedang dan pendek lebih efektif menghasilkan angka karena pola serangan menjadi lebih cepat dan mempersulit lawan untuk melakukan antisipasi datangnya bola. Smash dapat dilakukan dari semua posisi. Posisi empat, tiga dan dua, posisi ini yang sering dipergunakan untuk menyerang. Dari ketiga posisi tersebut seorang pelatih/guru harus memperhatikan tingkat kesulitan dan posisi yang paling efektif untuk menghasilkan angka sehingga mampu menyusun tim berdasarkan tipe-tipe pemain secara tepat. Tipe-tipe pemain dalam permainan bolavoli itu antara lain tipe pemain penyerang, tipe pemain bertahan, tipe pemain pengumpan, tipe pemain serba bisa. Smash adalah tindakan memukul bola ke bawah dengan kekuatan besar, biasanya meloncat ke atas, masuk ke bagian lapangan berlawanan. Hal itu dapat dilihat dari kerasnya bola yang dihasilkan bahwa teknik smash datangnya bola lebih keras dan lebih menyulitkan bagi penerima bola. Semua sikap memukul bola ke daerah lawan kecuali servis dan blok adalah merupakan pukulan serangan. Ada tiga metode penyerangan yang semuanya menjadi efektif yaitu melakukan tip: spike, pelan dan smash, keras. Teknik smash digunakan sebagai senjata untuk menyerang dan mengumpulkan angka dalam permainan bolavoli. Mengingat pentingnya hal tersebut maka pelaksanaan teknik smash dalam pertandingan harus efektif.

Telah diketahui bahwa betapa pentingnya kekuatan bagi hampir semua cabang olahraga. Oleh karena itu latihan strength harus senantiasa masuk dalam program latihan kondisi fisik untuk pemain. Namun apakah kekuatan sudah cukup bagi pemain untuk meningkatkan prestasinya, jawabannya tentu belum cukup karena orang yang memiliki kekuatan saja atau yang kuat ototnya belum cukup dengan sendirinya akan berprestasi tinggi apabila tidak mempunyai otot-otot yang cepat. Oleh karena itu pemain tidak hanya sekedar berlatih untuk meningkatkan kekuatannya saja, akan tetapi kekuatan tersebut haruslah ditingkatkan menjadi daya ledak (power). Kemampuan tenaga explosif di kenal pula dengan istilah tenaga otot, hal ini sepadan yang di kemukakan oleh Abdul Kadir Ateng (1992:140) bahwa: Tenaga otot yaitu kemampuan untuk melepaskan kekuatan otot secara maksimal dalam waktu sesingkat-singkatnya seseorng di katakan bertenaga penuh ( kemampuan tenaga explosif 


\section{e-ISSN: 2657-0703 dan p-ISSN: 2085-5389}

) adalah individu yang memiliki: a) tingkat kekuatan otot yang tinggi, b) tingkat kecepatan yang tinggi, c) tingkat kemampuan yang tinggi dalam mengintegrasikan kecepatan dan kekuatan otot. Yunus (1992:12) mengemukakan bahwa "permainan bolavoli harus memiliki potensi unsur-unsur kondisi fisik yang tinggi untuk dapat di kembangkan menjadi seorang pemain yang baik; kecepatan, power, stamina, koordinasi, kelentukan dan kelincahan". Daya ledak diperlukan hampir di semua cabang olahraga, oleh karena itu di dalam daya ledak terdapat unsur fisik yaitu kekuatan dan kecepatan. Harsono (2001:200) mengemukakan bahwa daya ledak 28 adalah kemampuan otot untuk mengarahkan kekuatan maksimal dalam waktu yang sangat cepat. Menurut Wahjoedi (2000:61) menyatakan, "Daya ledak (power) adalah kemampuan tubuh yang memungkinkan otot atau kelompok otot untuk bekerja secara eksplosif". Selanjutnya Sajoto (1995:8) mengemukakan bahwa power adalah kemampuan seseorang untuk melakukan kekuatan maksimum, dengan usaha yang dikerahkan dalam waktu yang sesingkatsingkatnya. Daya ledak merupakan suatu komponen biomotorik dalam kegiatan olahraga, karena daya ledak akan menetukan seberapa keras orang memukul, menendang seberapa jauh orang dapat melakukan tolakan serta seberapa cepat orang berlari dan sebaliknya. Daya ledak ialah kemampuan sebuah otot untuk mengatasi tahanan beban dengan kecepatan tinggi dalam situasi gerakan yang utuh (Suharto $\mathrm{Hp}$ ) dan menurut Sajoto (1988) adalah kemampuan seseorang melakukan kekuatan yang maksimal dengan usaha yang dikerahkan dalam waktu yang sependek-pendeknya. Tungkai adalah anggota gerak bagian bawah. Panjang tungkai melibatkan tulang-tulang dan otot-otot pembetuk tungkai baik tungkai adalah komponen kondisi fisik yang menyangkut masalah kemampuan seorang atlet pada saat menggunakan otot tungkai, menerima beban pada masa tertentu (M Sajoto, (1995:176). Unsur dasar power adalah perpaduan antara kekuatan dan kecepatan. Daya ledak otot tungkai dapat ditingkatkan dengan memberikan latihan kekuatan otot tungkai dan kecepatan gerak dari otot tungkai. Menurut Suharno HP (1993: 60) ciri-ciri latihan Power adalah : (1) Melawan beban relatif ringan, berat beban sendiri, dapat pula ditambahkan beban luar yang ringan, (2) Rerakan relatif aktif, dinamis, dan cepat, (3) Gerakan-gerakan merupakan satu gerak yang singkat, serasi dan utuh, (4) Bentuk gerak bisa cyclic atau acyclic, dan (5) Intensitas kerja ubmaksimal atau maksimal. Dari beberapa pendapat, dapat disimpulkan bahwa kekuatan merupakan kombinasi antara kekuatan dengan kecepatan untuk mengatasi beban dengan kecepatan kontrksi otot yang tinggi. Kekuatan menggambarkan kemampuan otot untuk mengatasi beban dengan mengangkat, menolak, mendorong. Sedangkan kecepatan menunjukan kemampuan otot untuk mengatasi beban dengan kontraksi yang sangat cepat, kekuatan otot dan kontraksi otot merupakan ciri utama kekuatan.

Menurut Moch. Sajoto (1988:53) bahwa: "Koordinasi adalah kemampuan untuk menyatukan berbagai sistem syaraf gerak yang terpisah, kedalam suatu pola gerak yang efisien.Maka kompleks gerak yang dilakukan, makin besar tingkat koordinasi yang diperlukan untuk melaksanakan ketangkasan tersebut. "Koordinasi berhubungan dengan kemampuan motorik lain,seperti koordinasi mata tangan,kecepatan dan agility" (Moch Sajoto, 1988:53). Pendapat Zernicke (1979) yang dikemukakan Harsono (1988) bahwa: "Koordinasi adalah perpaduan fungsi beberapa otot secara tepat dan seimbang menjadi satu pola gerak. Koordinasi mata tangan sangat penting baik dilapangan maupun di luar lapangan, terutama permainan beregu seperti bolavoli yang membutuhkan berbagai macam gerakan-gerakan kompleks. Koordinasi mata tangan adalah suatu kemampuan biometrik yang kompleks yang mempunyai hubungan erat dengan kecepatan, kekuatan, daya tahan dan kelentukan. Dalam permainan bolavoli khususnya teknik dasar smash membutuhkan gerakan yang kompleks, yang merupakan syarat utama dalam teknik tersebut. Koordinasi gerak mata tangan dan tangan adalah gerak yang terjadi dari informasi yang diintegrasikan kedalam gerak anggota badan, sesuai dengan urutan yang direncanakan untuk melakukan gerakan smash. Seorang pemain bolavoli yang memiliki koordinasi mata tangan yang baik, maka mampu mengkoordinasi komponenkomponen penggerakan tubuh,otot-otot tendong, persendian sebagai komponen utama dalam permainan bolavoli khususnya dalam 


\section{Volume 10 Nomor 3, Oktober 2018}

melakukan teknik smash. Latihan yang baik untuk meningkatkan koordinasi adalah dengan melakukan dengan berbagai variasi gerak dan keterampilan. Atlet-atlet yang mempunyai spesialisasi suatu cabang olahraga tertentu sebaiknya dilibatkan dalam berbagai cabang olahraga yang lainnya. Didalam melakukan keterampilan-keterampilan gerak, faktor kesulitan dan kompleksitas gerakan harus senantiasa digantikan. Koordinasi paling mudah di kembangkan pada anak" usia muda, yaitu pada waktu kemampuan adaptasi nervous sistemnya lebih baik daripada kepunyaan orang dewasa, karena faktor usia turut mempengaruhi kemampuan gerak seseorang.

Setiap regu selalu berusaha untuk melakukan serangan, yaitu melewati net kearah lapangan lawan sedemikian rupa,sehingga lawan sulit atau tidak dapat mengembalikan bola atau menangkisnya. Serangan biasanya berupa pukulan keras yang disebut smash.Smash adalah tindakan memukul bola kebawah dengan kekuatan penuh, biasanya melompat keatas, masuk kebagian lapangan lawan. Smash merupakan suatu teknik yang mempunyai gerakan yang kompleks yang terdiri dari: Langka awal, tolakan untuk meloncat, memukul bola saat melayang diudara dan saat mendarat kembali setelah memukul bola (Yunus,1992:101). Hal itu dapat dilihat dari kerasnya bola yang dihasilkan bahwa teknik smash datangnya bola lebih keras dan menyulitkan bagi penerima bola. Smash merupakan teknik serangan yang bertujuan agar bola dapat mendarat di area lawan, tanpa bisa di blok atau (di tahan).Dalam teknik smash ini, seorang smasher (penyerang), harus memperhatikan empat, langka dasar dalam melakukan smash,yaitu awalan (approach), lompatan, ayunan, pukulan pada bola di udara dan posisi mendarat (Yunus1992:153). Masher dapat menyerang dengan efektif apabila memperhatikan faktor-faktor yaitu; Kualitas pemberian bola, (2) Block pihak posisi (lawan), (3) Posisi pertahanan dari pihak lawan, (4) Kemampuan teknik pihak smasher, (5) Kondisi regunya dan regu lawan, dan (6) Teknik smash bolavoli.

Dalam permainan bolavoli smash di definisikan tindakan memukul boladengan meloncat dan masuk ke lapangan lawan. Tindakan memukul bola (smash), ada beberapa tahap. Menurut Beutelstahl (1989:23), tahapan tersebut adalah: (1) Tahap pertama : Run up (lari menghampiri), (2) Tahap kedua : Take off (lepas landas), (3) Tahap ketiga : Hit (memukul saat melayang di udara), dan (4) Tahap keempat : Landing (mendarat)

\section{METODE PENELITIAN}

Metode yang digunakan dalam penelitian ini adalah metode deskriptif. Dalam penelitian ini terdiri dari daya ledak tungkai dan koordinasi mata tangan sebagai variabel bebas dan kemampuan smash bolavoli sebagai variabel terikat. Populasi dalam penelitian ini adalah mahasiswa Program Studi Pendidikan Kepelatihan Olahraga Fakultas Olahraga dan Kesehatan Universitas Negeri Gorontalo berjumlah dengan sampel sebanyak 30 orang yang diperoleh dengan teknik sampel acak (random sampling). Data yang terkumpul tersebut perlu dianalisis secara statistik deskriptif, maupun infrensial untuk keperluan pengujian hipotesis penelitian. Jadi keseluruhan analisis data statistik yang digunakan pada umumnya menggunakan analisis komputer pada program SPSS versi 20.00 dengan taraf signifikan $95 \%$ atau atau $\alpha=0,05$.

\section{HASIL DAN PEMBAHASAN}

Hasil analisis deskriptif data data daya ledak tungkai dan data koordinasi mata tangan terhadap kemampuan smash pada permainan bolavoli sebagai berikut.

Tabel 1.

Hasil analisis deskriptif data tiap variabel.

\begin{tabular}{|c|c|c|c|c|c|c|}
\hline \multirow{2}{*}{ Variabel } & \multicolumn{6}{|c|}{ Nilai Statistik } \\
\cline { 2 - 7 } & $\mathrm{N}$ & Mean & Sd. & Min. & Max. & Range \\
\hline Daya ledak lengan & 30 & 2,0940 & .37553 & 1,30 & 2,54 & 1,24 \\
\hline Daya ledak tungkai & 30 & 59,2667 & 5,68685 & 51 & 70 & 19 \\
\hline
\end{tabular}


e-ISSN: 2657-0703 dan p-ISSN: 2085-5389

\begin{tabular}{|c|c|c|c|c|c|c|}
\hline \multirow{2}{*}{ Variabel } & \multicolumn{6}{|c|}{ Nilai Statistik } \\
\cline { 2 - 7 } & $\mathrm{N}$ & Mean & Sd. & Min. & Max. & Range \\
\hline Koordinasi mata tangan & 30 & 24,9667 & 4,95833 & 17 & 31 & 14 \\
\hline $\begin{array}{c}\text { Kemampuan smash } \\
\text { bolavoli }\end{array}$ & 30 & 2,4667 & 1,25212 & 1 & 4 & 3 \\
\hline
\end{tabular}

Untuk pengujian hipotesis tersebut maka dilakukan uji korelasi dan regresi data hubungan daya ledak tungkai dan koordinasi mata tangan terhadap kemampuan smash bolavoli mahasiswa Program Studi Pendidikan Kepelatihan Olahraga Fakultas Olahraga dan Kesehatan Universitas Negeri Gorontalo.

a. Ada hubungan daya ledak tungkai terhadap kemampuan smash bolavoli mahasiswa Program Studi Pendidikan Kepelatihan Olahraga Fakultas Olahraga dan Kesehatan Universitas Negeri Gorontalo

Hasil data yang diperoleh dari penelitian bertujuan untuk mengetahui antara variable bebas dan variable terikat serta membuktikan hipotesis yang ada. Oleh karena itu hasil pengujian hipotesis berdasarkan pengolahan data melalui analisis korelasi dan regresi dari program SPSS tentang hubungan daya ledak otot tungkai terhadap kemampuan smash dalam permainan bolavoli pada mahasiswa Program Studi Pendidikan Kepelatihan Olahraga Fakultas Olahraga dan Kesehatan Universitas Negeri Gorontalo diperoleh sesuai rangkuman tabel 2 berikut:

Tabel 2.

Hasil analisis korelasi dan regresi untuk hipotesis pertama

\begin{tabular}{|c|c|c|c|c|c|}
\hline VARIABEL & $\mathbf{r} / \mathbf{R}$ & Rs & $\mathbf{F}$ & $\mathbf{t}$ & Sig. \\
\hline Daya ledak tı & \multirow{2}{*}{0,823} & \multirow{2}{*}{0,678} & \multirow{2}{*}{79,992} & \multirow{2}{*}{8,944} & \multirow{2}{*}{0,000} \\
\hline Smash bolavoli (Y) & & & & & \\
\hline
\end{tabular}

Hipotesis statistik :

Ho : $r_{x 1 y}=0$

$\mathrm{H} 1: \quad \mathrm{r}_{\mathrm{x} 1 \mathrm{y}} \neq 0$

Hasil pengujian :

Berdasarkan hasil pengujian analisis data daya ledak tungkai terhadap kemampuan smash bolavoli pada mahasiswa Program Studi Pendidikan Kepelatihan Olahraga Fakultas Olahraga dan Kesehatan Universitas Negeri Gorontalo, diperoleh nilai korelasi observasi ( $\left.r_{0}\right) 0,823$ dengan tingkat probabilitas $(0,000)<$ $\alpha_{0,05}$. Untuk nilai $\mathrm{R}$ Square (koefesien determinasi) 0,678. Hal ini berarti $67,8 \%$ kemampuan smash bolavoli dijelaskan oleh daya ledak otot tungkai. Dari uji Anova atau F test, didapat $F$ hitung adalah 79,992 dengan tingkat signifikansi 0,000 . Oleh karena probabilitas $(0,000)$ jauh lebih kecil dari $\alpha_{0,05}$, maka model regresi dapat dipakai untuk memprediksi kemampuan smash bolavoli (dapat diberlakukan untuk populasi dimana sampel diambil). Dari uji t diperoleh 8,944 dengan tingkat signifikansi 0,000 . Oleh karena probabilitas $(0,000)$ jauh lebih kecil dari $\alpha_{0,05}$. Maka Ho ditolak dan $\mathrm{H}_{1}$ diterima atau koefesien regresi signifikan, atau daya ledak otot tungkai benar-benar berpengaruh secara signifikan terhadap kemampuan smash bolavoli. Dengan demikian dapat disimpulkan bahwa ada hubungan yang signifikan daya ledak otot tungkai terhadap kemampuan smash bolavoli pada mahasiswa Program Studi Pendidikan Kepelatihan Olahraga Fakultas Olahraga dan Kesehatan Universitas Negeri Gorontalo sebesar terbukti korelasi observasi ( $\left.\mathrm{r}_{0}\right) \quad 0,823$ dengan tingkat probabilitas $(0,000)<\alpha_{0,05}$

\section{b. Ada hubungan koordinasi mata tangan terhadap kemampuan smash bolavoli mahasiswa Program Studi Pendidikan Kepelatihan Olahraga Fakultas Olahraga dan Kesehatan Universitas Negeri Gorontalo}

Hasil data yang diperoleh dari penelitian bertujuan untuk mengetahui antara variable bebas dan variable terikat serta membuktikan hipotesis yang ada. Oleh karena itu hasil pengujian hipotesis berdasarkan pengolahan 


\section{Volume 10 Nomor 3, Oktober 2018}

data melalui analisis korelasi dan regresi dari program SPSS tentang hubungan koordinasi mata tangan terhadap kemampuan smash bolavoli pada mahasiswa Program Studi
Pendidikan Kepelatihan Olahraga Fakultas Olahraga dan Kesehatan Universitas Negeri Gorontalo diperoleh sesuai rangkuman tabel 3 berikut:

Tabel 3.

Hasil analisis korelasi dan regresi untuk hipotesis kedua

\begin{tabular}{|c|c|c|c|c|c|}
\hline VARIABEL & r/R & Rs & F & t & Sig. \\
\cline { 1 - 3 } Koordinasi mata tangan (X1) & 0,646 & 0,417 & 27,158 & 5,211 & 0,000 \\
\cline { 1 - 1 } Pukulan forehand tenismeja (Y) & & & & & \\
\hline
\end{tabular}

Hipotesis statistik :

Ho : $r_{x 2 y}=0$

$\mathrm{H} 1: \mathrm{r}_{\mathrm{x} 2 \mathrm{y}} \neq 0$

Hasil pengujian :

Berdasarkan hasil pengujian analisis data koordinasi mata tangan terhadap kemampuan smash bolavoli pada mahasiswa Program Studi Pendidikan Kepelatihan Olahraga Fakultas Olahraga dan Kesehatan Universitas Negeri Gorontalo, diperoleh nilai korelasi observasi ( $\left.\mathrm{r}_{0}\right)$ 0,646 dengan tingkat probabilitas $(0,000)<\alpha_{0,05}$. Untuk nilai $R$ Square (koefesien determinasi) 0,417. Hal ini berarti $41,7 \%$ kemampuan smash bolavoli dijelaskan oleh koordinasi mata tangan. Dari uji Anova atau $\mathrm{F}$ test, didapat $\mathrm{F}$ hitung adalah 27,158 dengan tingkat signifikansi 0,000 . Oleh karena probabilitas $(0,000)$ jauh lebih kecil dari $\alpha_{0,05}$, maka model regresi dapat dipakai untuk memprediksi kemampuan smash bolavoli (dapat diberlakukan untuk populasi dimana sampel diambil). Dari uji $t$ diperoleh 5,211 dengan tingkat signifikansi 0,000 . Oleh karena probabilitas $(0,000)$ jauh lebih kecil dari $\alpha_{0,05}$. Maka Ho ditolak dan $\mathrm{H}_{1}$ diterima atau koefesien regresi signifikan, atau koordinasi mata tangan benar-benar berpengaruh secara signifikan terhadap kemampuan smash bolavoli. Dengan demikian dapat disimpulkan bahwa ada hubungan yang signifikan koordinasi mata tangan terhadap kemampuan smash bolavoli pada mahasiswa Program Studi Pendidikan Kepelatihan Olahraga Fakultas Olahraga dan Kesehatan Universitas Negeri Gorontalo terbukti nilai korelasi observasi ( $\left.r_{0}\right) \quad 0,646$ dengan tingkat probabilitas $(0,000)<\alpha_{0,05}$.

\section{c. Ada hubungan daya ledak tungkai dan koordinasi mata tangan terhadap kemampuan smash bolavoli mahasiswa Program Studi Pendidikan Kepelatihan Olahraga Fakultas Olahraga dan Kesehatan Universitas Negeri Gorontalo}

Hasil data yang diperoleh dari penelitian bertujuan untuk mengetahui antara variable bebas dan variable terikat serta membuktikan hipotesis yang ada. Oleh karena itu hasil pengujian hipotesis berdasarkan pengolahan data melalui analisis regresi dari program SPSS tentang hubungan daya ledak otot tungkai dan koordinasi mata tangan terhadap kemampuan smash bolavoli pada mahasiswa Program Studi Pendidikan Kepelatihan Olahraga Fakultas Olahraga dan Kesehatan Universitas Negeri Gorontalo diperoleh sesuai rangkuman tabel 4 berikut:

Tabel 4.

Hasil analisis regresi untuk hipotesis ketiga

\begin{tabular}{|c|c|c|c|c|c|}
\hline VARIABEL & $\mathbf{r} / \mathbf{R}$ & Rs & $\mathbf{F}$ & $\mathbf{t}$ & Sig. \\
\hline $\begin{array}{l}\text { Daya ledak otot tungkai (X2) } \\
\text { Smash open bolavoli (Y) }\end{array}$ & 0,829 & 0,688 & 40,744 & 4,000 & 0,000 \\
\hline
\end{tabular}

\section{SIMPULAN DAN SARAN}

1. Daya ledak tungkai memberi hubungan terhadap kemampuan smash bolavoli pada Mahasiswa Program Studi Pendidikan
Kepelatihan Olahraga Fakultas Olahraga dan Kesehatan Universitas Negeri Gorontalo.

2. Koordinasi mata tangan memberi hubungan terhadap kemampuan smash 
bolavoli pada Mahasiswa Program Studi Pendidikan Kepelatihan Olahraga Fakultas Olahraga dan Kesehatan Universitas Negeri Gorontalo.

3. Daya ledak tungkai, dan Koordinasi mata tangan memberi hubungan terhadap kemampuan smash bolavoli pada Mahasiswa Program Studi Pendidikan Kepelatihan Olahraga Fakultas Olahraga dan Kesehatan Universitas Negeri Gorontalo.

Berdasarkan hasil penelitian yang disimpulkan tersebut di atas, maka disarankan kepada :

1. Bagi Pelatih dan Pembina olahraga, agar di dalam memilih atlet bolavoli yang ingin dikembangkan harus memperhatikan unsur daya ledak tungkai, dan koordinasi mata tangan sebagai penunjang dalam melakukan permainan bolavoli.

2. Bagi atlet, untuk meraih prestasi yang baik dalam permainan bolavoli memerlukan kerja keras dan latihan yang kontinyu dan berkaitan dengan teknik dasar permainan bolavoli.

3. Program Studi Pendidikan Kepelatihan Fakultas Olahraga dan Kesehatan merupakan suatu wadah untuk memperoleh ilmu yang hubungan dengan olahraga, sehingga hasil penelitian ini dapat dijadikan ilmu yang berguna sebagai bahan masukan.

\section{DAFTAR RUJUKAN}

Beutelstahl Dieter. 2007. Belajar Bermain Bola Volley.Bandung : PT Pioner Jaya.

Griwijoyo, Santosa. 2007. ilmu faal olahraga fungsi tubuh manusia pada olahraga, Bandung. FPUK.UPI

Harsono. 2001. Coaching dan Aspek-Aspek Psikologis Dalam Coaching. Jakarta: CV. Tambak Kusuma.

Nuril Ahmadi. 2007. Panduan Olahraga Bolavoli. Solo: Era Pustaka Utama.

Sajoto, M., 1995. Pembinaan Kondisi Fisik Dalam Olahraga. Prahara Princes, Semarang.

Wahjoedi.2000. Landasan Pendidikan Jasmani, PT. Raja Grafindo Persada

Widiastuti.2011. Tes dan Pengukuran, Jakarta: PT.Timur Jaya

Yunus.(1992). Olahraga pilihan bolavoli. Jakarta : Dep P dan K. 